\title{
Novel Benzofused five membered nitrogen containing heterocyclic compound N-substituted- 2-substituted Benzimidazole: Synthesis and Molecular Docking
}

\author{
Patil Tejaswini D. ${ }^{1 *}$, Amrutkar Sunil V. ${ }^{2}$, Dr. Chaudhari Praveen D. ${ }^{3}$ \\ ${ }^{1}$ Ph.D. Scholar, Department of Pharmaceutical Chemistry, Progressive Education Society's, Modern College of \\ Pharmacy, Nigadi, Pune, Maharashtra. \\ ${ }^{2}$ Professor and Principal, Department of Pharmaceutical Chemistry, Gokhale Education Society’s Sir Dr. M. S. \\ Gosavi College of Pharmaceutical Education and Research, Nashik, Maharashtra \\ ${ }^{3}$ Professor and Principal, Progressive Education Society’s, Modern College of Pharmacy, Nigadi, Pune,
}

Maharashtra

\begin{abstract}
Background: The major cause of sickness and death is infectious diseases worldwide. As bacteria develop resistance at a quicker pace, novel antimicrobial compounds with various sites of action and sensitivity to resistant bacteria, as well as safety, are needed as a superior alternative to currently existing treatments. Heterocyclic compounds have long caught the interest of researchers due to their broad spectrum of applications and convenience of modification, dating back to the early days of chemical study. In medicinal chemistry, the benzimidazole molecule is a prominent pharmacophore and preferred structure.

Method: The method described in the literature was used to synthesize benzimidazole and mercapto-benzimidazole utilising microwave irradiation. In the presence of $\mathrm{K} 2 \mathrm{CO}$, benzimidazole/mercapto-benzimidazole was reacted with 2chloro-N-substituted acetamide to produce desirable $\mathrm{N}$-substituted-2-substituted benzimidazole derivatives (5a-1). Microwave irradiation speeds up the process and reduces impurities. IR, 1HNMR, 13CNMR and MS is used to confirm the structure of synthesised derivatives.A molecular docking investigation was done on two protein targets, DNA gyrase subunit B (5L3J) and Staphylococcus aureus tyrosyl-tRNA synthetase (1JIJ), using a typical docking technique.

Result: The desired compounds were synthesised with excellent purity and yield by Microwave aided synthesis. 5d, 5e, and $5 \mathrm{k}$ have a high yield.The biological activity of derivatives on a given target side can be predicted via a molecular docking research. The docking score indicates that they have a stronger binding contact than the reference ligand. The maximum binding affinity is found in $5 \mathrm{c}, 5 \mathrm{e}$, and $5 \mathrm{k}$.

Conclusion: According to the findings, compounds $5 \mathrm{c}, 5 \mathrm{~d}, 5 \mathrm{e}$ and $5 \mathrm{k}$ show a strong potential for antibacterial action. The potency of benzimidazole derivatives might be improved with more SAR studies.
\end{abstract}

Keywords-N-substituted benzimidazole, Molecular docking, DNA gyrase, auotodock viva, microwave assisted synthesis

\section{INTRODUCTION}

Infectious agents of over 1400 different species have been found to cause infections in humans. Pathogens for 347 illnesses of long-term clinical relevance were amongst them.[1] According to WHO study, microbial illness could become one of the leading reasons for human death in the near future.[2]Because of the production, transmission, and survival of multidrug-resistant microorganisms, which cause diseases that do not respond to normal therapies, antibiotic resistance is one of the most important public health challenges of the twenty-first century.[3] Furthermore, infection produced by a variety of bacteria is a severe problem for the medical community, and the create necessity for the discovery for new antimicrobial medicines as an efficient treatment.[4] One of the most efficient antibacterial medications are heterocyclic molecules containing nitrogen atoms.[5] A phenyl ring is fused to an imidazole ring in benzimidazoles.[6] Benzimidazole derivatives have been linked to a variety of pharmacological actions, including antibacterial, anticancer, and anti-inflammatory properties, according to the literature. [7-9]This broad spectrum of activity is attributed to the unusual chemical characteristics of azole rings, which are able to interact noncovalently with 


\section{International Advanced Research Journal in Science, Engineering and Technology}

Vol. 8, Issue 6, June 2021

DOI: $10.17148 /$ IARJSET.2021.8691

a variety of targets due to the presence of an electron-rich aromatic structure and heteroatoms.[10] The goal of this study is to synthesise some new $\mathrm{N}$-substituted-2-substituted benzimidazoles and anticipate their bacterial activity using molecular docking against two targets: E. Coli DNA gyrase subunit B (5L3J) and tyrosyl t-RNA synthetase (1JIJ).

\section{EXPERIMENTAL METHODS OR METHODOLOGY}

\subsection{Chemistry:}

All chemicals were procured by commercial supplier and utilized without additional purification. reaction was monitored by TLC, and the melting point was measured and corrected using the open capillary method.

Vertex 80 FTIR was used to record Infrared (IR) spectra and ECZR Series $600 \mathrm{MHz}$ was used to obtain ${ }^{1} \mathrm{H}-\mathrm{NMR}$ and ${ }^{13} \mathrm{C}-\mathrm{NMR}$. AccuTOF GCV mass spectrometer and FLASH EA 1112 series analyser was used to record mass spectra and CHNS analysis respectively.

2.1.a. General Procedure for the Synthesis of 2-chloro- $N$ - substituted acetamide (2a-g): [11,12]

With continuous shaking, $0.01 \mathrm{M}$ of substituted aromatic amine (1) was introduced to a conical flask containing a $10 \%$ $\mathrm{NaOH}$ solution. In a fuming hood, the conical flask was cooled on an ice bath, and $(0.015 \mathrm{M})$ chloro acetyl chloride was added drop by drop using a dropping funnel. The solution was stirred on magnetic stirrer until complete addition of chloro acetyl chloride and fumes from the reaction mixture ceased completely. The solution was then stirred overnight. The target product $(2 \mathrm{a}-\mathrm{g})$ was isolated as a precipitate after dumping the reaction mixture into ice-cold water. The filtered precipitate was rinsedwith cold water and dried. $95 \%$ ethanol was used to re-crystallize it.

2.1.b. General Procedure for the Synthesis of 2-(1H-benzimidazol-1-yl)-N-substituted-2-substituted acetamide $(5 \mathbf{a}-\mathbf{l})[13]$

Microwave irradiation was used to synthesise benzimidazole(3)[14], as described in the literature using o-phenylene diamine $(0.025 \mathrm{~mol})$ and $90 \%$ formic acid $(0.034 \mathrm{~mol})$. The general procedure given by wang and liu was used for preparing 2- mercapto benzimidazole (4).[15-17]

The final desired product was prepared by refluxing 2-chloro-N-Aryl acetamide derivative (2a-g) (0.02mole) and Benzimidazole/ mercaptobenzimidazole $(0.02 \mathrm{~mole})$ in DMF in the presence of potassium carbonate and potassium iodide using microwave irradiation at $245 \mathrm{~W}$. TLC was used to monitor the reaction's progress. After the reaction was completed, the solution was poured into ice-cold water, and the precipitate was filtered, dried, and recrystallized using ethanol. $[13,18]$
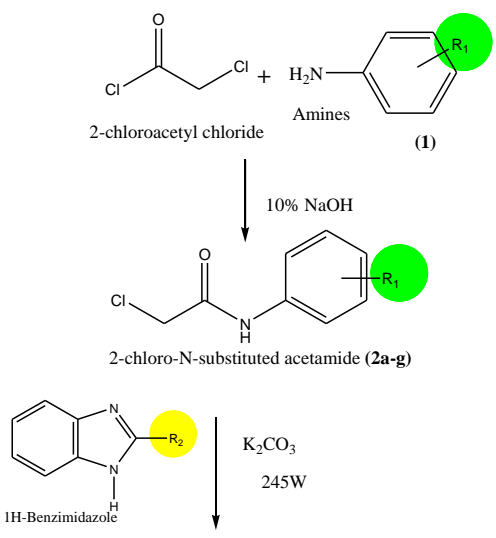

$(3 / 4)$

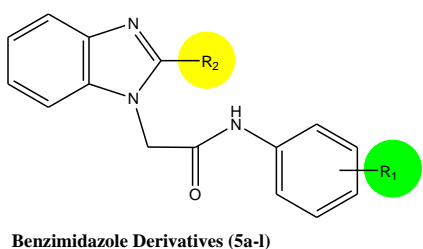

Fig.1. Scheme for synthesis of benzimidazole derivatives

\section{2-(1-H-Benzimidazol-1-yl)-N-phenylacetamide (5a)}

IR (KBr) $\gamma_{\max }\left(\mathrm{cm}^{-}\right)$: 3337.23 (N-H str.), 2918.51 (=C-H str.), 1688.41 (C=O str.), 1513.03 (N-H bend) ,1460.10 (C-N str.), 819.19-738.00(Aromatic ring); ${ }^{1} \mathrm{H}$ NMR (600 MHz, $\left.\delta \mathrm{ppm}\right): 3.84\left(\mathrm{~s}, \mathrm{CH}_{2}\right), 4.98(\mathrm{~s},=\mathrm{CH}-\mathrm{N}), 8.14(\mathrm{~s}, \mathrm{NH})$, 7.55(d,=CH benzimidazole), 7.44(d,=CH benzimidazole), 7.29-6.97(m, $\mathrm{CH} \mathrm{Ar}) ;{ }^{13} \mathrm{C} \mathrm{NMR}(600 \mathrm{MHz}, \delta \mathrm{ppm}): 39.84$ $\left(\mathrm{CH}_{2}\right), 165.73(\mathrm{C}=\mathrm{O}), 119.73-110.91(\mathrm{CH}$ Ar.),146.53 (CH-Imidazole), 136-125.49(CH- Benzimidazole) ; Anal. Cal. (Found) for $\mathrm{C}_{15} \mathrm{H}_{13} \mathrm{~N}_{3} \mathrm{O}: \mathrm{C} 66.52$ (62.54), H 5.21(4.83), N 16.26 (14.13), O 5.65 (5.92); m/z: 254.02( $\mathrm{M}^{+}$). 
International Advanced Research Journal in Science, Engineering and Technology

Vol. 8, Issue 6, June 2021

DOI: $10.17148 /$ IARJSET.2021.8691

2-(1-H-Benzimidazol-1-yl)-N-(p-tolyl) acetamide (5b)

IR (KBr) $\gamma_{\max }\left(\mathrm{cm}^{-}\right)$: 3259.81 (N-H str.), 3043.77 (=C-H str.), 1658.84 (C=O str.), 1543.10 (N-H bend), 1435.09 (C-N str.), 785-652(Aromatic ring). ${ }^{1} \mathrm{H}$ NMR $(600 \mathrm{MHz}, \delta \mathrm{ppm}): 2.14\left(\mathrm{~s}, \mathrm{CH}_{3}\right), 3.89\left(\mathrm{~s}, \mathrm{CH}_{2}\right), 8.31$ (s, CH-imidazole), 7.35(NH amide), 7.25 ( $\mathrm{d},=\mathrm{CH}$ benzimidazole), 7.36(d,=CH benzimidazole), 6.72-6.46(d, $\mathrm{CH} \mathrm{Ar}),{ }^{13} \mathrm{C} \mathrm{NMR}(600 \mathrm{MHz}, \delta \mathrm{ppm})$ : $25.02\left(\mathrm{CH}_{3}\right), 39.63\left(\mathrm{CH}_{2}\right), 166.04(\mathrm{C}=\mathrm{O}), 117.94-115.22(\mathrm{CH}$ Ar. $), 149.98$ (CH-Imidazole), 136.94-123.72(CHBenzimidazole), $\mathrm{m} / \mathrm{z}: 264.99\left(\mathrm{M}^{+}\right)$

2-(1-H-Benzimidazol-1-yl)-N-(p-chlorophenyl) acetamide (5c)

IR (KBr) $\gamma_{\max }\left(\mathrm{cm}^{-}\right)$: 3267.52 (N-H str.), 3128.64 (=C-H str.), 1670.71 (C=O str.), 1537.32 ( $\mathrm{N}-\mathrm{H}$ bend) ,1491.02 (C-N str.), 831.36(Aromatic ring), $668.30(\mathrm{C}-\mathrm{Cl})$.

2-(1-H-Benzimidazol-1-yl)-N-(p-nitrophenyl) acetamide (5d)

IR (KBr) $\gamma_{\max }\left(\mathrm{cm}^{-}\right): 3263.66$ (N-H str.), 3068.85 (=C-H str.), 1687.77 (C=O str.), 1591.33 (N-H bend) ,1464.66 (C-N str.), 1591.30 and 1446.66 ( $\mathrm{NO}_{2}$ str.), $758-642$ (Aromatic ring); ${ }^{1} \mathrm{H}$ NMR (600 MHz, $\delta \mathrm{ppm}$ ): $3.98\left(\mathrm{~s}, \mathrm{CH}_{2}\right), 7.91(\mathrm{~s}, \mathrm{CH}-$ imidazole), $7.48\left(\mathrm{NH}\right.$ amide), $7.29(\mathrm{~d}=\mathrm{CH}$ benzimidazole $), 7.59(\mathrm{~d}=\mathrm{CH}$ benzimidazole $), 6.95-6.93(\mathrm{~d}, \mathrm{CH} \mathrm{Ar}) .{ }^{13} \mathrm{C}$ $\operatorname{NMR}(600 \mathrm{MHz}, \delta \mathrm{ppm}): 39.52\left(\mathrm{CH}_{2}\right), 168.25(\mathrm{C}=\mathrm{O}), 109.81-107.05(\mathrm{CH}$ Ar.),148.76 (CH-Imidazole), 129.96120.00(CH- Benzimidazole), Anal. Cal. (Found) for $\mathrm{C}_{15} \mathrm{H}_{12} \mathrm{~N}_{4} \mathrm{O}_{3}: \mathrm{C} 60.81$ (61.68), H 4.08(3.63), N 19.91 (20.45), O $16.20(16.92), \mathrm{m} / \mathrm{z}: 296.46\left(\mathrm{M}^{+}\right)$.

2-(1-H-Benzimidazol-1-yl)-N-(o-nitrophenyl) acetamide (5e)

IR (KBr) $\gamma_{\max }\left(\mathrm{cm}^{-}\right)$: 3213.77 (N-H str.), 3062.24 (=C-H str.), 1679.89 (C=O str.), 1587.34 ( $\mathrm{N}-\mathrm{H}$ bend) ,1458.85 (C-N str.), 1619.04 and 1458.85 ( $\mathrm{NO}_{2}$ str.), 768-634(Aromatic ring).

2-(1-H-Benzimidazol-1-yl)-N-(p-fluorophenyl) acetamide (5f)

IR (KBr) $\gamma_{\max }\left(\mathrm{cm}^{-}\right): 3271.38$ (N-H str.), 3053.42 (=C-H str.), 1668.48 (C=O str.), 1543.10 (N-H bend) ,1475.59 (C-N str.), 785-540(Aromatic ring), 1062.52 (C- F)

2-(1-H-Benzimidazol-1-yl)-N-(p-methoxyphenyl) acetamide (5g)

IR (KBr) $\gamma_{\max }\left(\mathrm{cm}^{-}\right)$: 3279.10 (N-H str.), 3107.43 (=C-H str.), 1670.41 (C=O str.), 1591.33 (N-H bend) ,1475.59 (C-N str.), 785-652(Aromatic ring), 1070.53(O-C str.)

2-(2-mercapto-1H-benzo[d]imidazole- 1-yl)-N-phenylacetamide (5h)

IR (KBr) $\gamma_{\max }\left(\mathrm{cm}^{-}\right)$: 3211.7 (N-H str.), 2977.6 (=C-H str.), 2929.2(-SH str.), 1671.6 (C=O str.), 1594.0 (N-H bend) ,1251.3 (C-N str.), 798.6-698.0(Aromatic ring); ${ }^{1} \mathrm{H}$ NMR (600 MHz, $\left.\delta \mathrm{ppm}\right): 4.36\left(\mathrm{~s}, \mathrm{CH}_{2}\right), 8.38(\mathrm{~s}, \mathrm{NH}), 7.90(\mathrm{~d},=\mathrm{CH})$, $7.87(\mathrm{~d},=\mathrm{CH}), 7.74-7.05\left(\mathrm{~m}, \mathrm{CH}_{2} \mathrm{Ar}\right), 12.4(\mathrm{~s}, \mathrm{SH}) ;{ }^{13} \mathrm{C} \mathrm{NMR}(600 \mathrm{MHz}, \delta \mathrm{ppm}): 39.63\left(\mathrm{CH}_{2}\right), 164.47(\mathrm{C}=\mathrm{O}), 168.11(\mathrm{C}-$ $\mathrm{SH}$ ), 119.85-109.54(CH Ar.),133.90-122.37(CH- Benzimidazole) ; m/z: 283(M+), Anal. Cal. (Found) for $\mathrm{C}_{15} \mathrm{H}_{13} \mathrm{~N}_{3} \mathrm{OS}$ : C 63.58 (62.91), H 4.62(4.81), N 14.84 (14.93), O 5.65 (5.92), S 11.32 (10.65).

2-(2-mercapto-1H-benzo[d]imidazole- 1-yl)-N-(p-tolyl) acetamide (5i)

IR (KBr) $\gamma_{\max }\left(\mathrm{cm}^{-}\right)$: 3335.17 (N-H str.), 3113.80(=C-H str.), 2985.92(-SH str.), 1652.91 (C=O str.), 1514.15 (N-H bend), 1260.78 (C-N str.), 789.72-718.17 (Aromatic ring).

2-(2-mercapto-1H-benzo[d]imidazole- 1-yl)-N-(4-chlorophenyl) acetamide (5j)

IR (KBr) $\gamma_{\max }\left(\mathrm{cm}^{-}\right)$: 3211.4 (N-H str.), 2976.3(=C-H str.), 2928.3(-SH str.),1673.2 (C=O str.), 1533.9(N-H bend), 1251.7 (C-N str.), 798.8-717.8 (Aromatic ring), $698.2(\mathrm{C}-\mathrm{Cl}),{ }^{1} \mathrm{H}$ NMR (600 MHz, $\delta \mathrm{ppm}$ ): $4.75\left(\mathrm{~s}, \mathrm{CH}_{2}\right), 7.25(\mathrm{~s}, \mathrm{NH})$, 7.87(d,=CH), $7.73(\mathrm{~d},=\mathrm{CH}), 7.71-7.09\left(\mathrm{~m}, \mathrm{CH}_{2} \mathrm{Ar}\right), 12.54(\mathrm{~s}, \mathrm{SH}) ;{ }^{13} \mathrm{C} \mathrm{NMR}(600 \mathrm{MHz}, \delta \mathrm{ppm}): 39.63\left(\mathrm{CH}_{2}\right)$, 164.47(C=O),168.07(C-SH), 113.38-109.54(CH Ar.), 122.36-119.70 (=CH Benzoimidazole), 134.46(C-Cl); m/z: $317\left(\mathrm{M}^{+}\right)$, Anal. Cal. (Found) for $\mathrm{C}_{15} \mathrm{H}_{12} \mathrm{ClN}_{3} \mathrm{OS}$ : C 56.69 (55.94), H 3.81(3.62), N 13.22 (12.53), O 5.03 (5.20) S $10.09(9.63)$

2-(2-mercapto-1H-benzo[d]imidazole- 1-yl)-N-(4-nitrophenyl) acetamide (5k)

IR (KBr) $\gamma_{\max }\left(\mathrm{cm}^{-}\right)$: 3258.94(N-H str.), 3093.39(=C-H str.), 2951.71(-SH str.),1666.08 (C=O str.), 1593.47 (N-H bend), 1626.01 and 1405.52 ( $\mathrm{NO}_{2}$ str.), 1291.57 (C-N str.).

2-(2-mercapto-1H-benzo[d]imidazole- 1-yl)-N-(4-fluorophenyl) acetamide (5l)

IR (KBr) $\gamma_{\max }\left(\mathrm{cm}^{-}\right)$: 3369.4 (N-H str.), 2918.7 (=C-H str.), 2850.2(-SH str.), 1675.7 (C=O str.), 1553.3 (N-H bend), 1269.3 (C-N stre), 793.9-705.6 (Aromatic ring), 1069.4 (C- F)

2.2. Molecular Docking Study:

2.2.a. Target selection:

The 3D structure of E. Coli DNA gyrase subunit B (5L3J) and tyrosyl t-RNA synthetase (1JIJ) was acquired from the RCSB Protein Data Bank (https://www.rcsb.org).

2.2.b. Target protein Preparation:

Pymol software [19] was used to invent the active site of the target protein and Discovery studio visualizer[20]was used find the active site amino acid that were used for creating the grid box. The proteins were prepared for docking and saved in proper format (PDBQT) after removal of the bonded ligand, water molecule and hetero atom.

2.2.c. Ligand preparation:

2D structures of derivatives were drawn using Chemdraw Ultra program V.12.0.2 [21] and then converted to the docking-compatible formats PDB and PDBQT using Open Babel (version 3.0.0).[22] 


\section{International Advanced Research Journal in Science, Engineering and Technology}

Vol. 8, Issue 6, June 2021

DOI: $10.17148 /$ IARJSET.2021.8691

\section{2.d. Molecular docking protocol:}

A ligand molecule library was screened against E. coli DNA gyrase subunit B (5L3J) and tyrosyl t-RNA synthetase using Autodock Vina (1JIJ). [23,24] For identifying the interaction of ligand molecules with targeted proteins, the searching grid for the active site was built according to the visualisation in Discovery studio. The grid box was centred at the binding site and was 60 X 60 X $60 \AA^{3}$. Then Kollman charges, Gasteiger-type polar hydrogen charges, and polar hydrogen were allocated along with internal degrees of freedom and torsions[25]. The results were evaluated by ranking the different complexes according to their predicted binding energy. A more in-depth study of the protein-ligand interaction was performed using the Discovery Studio Visualizer tool [26].

\section{RESULTS AND DISCUSSION}

\subsection{Chemistry:}

The intended product was produced by condensing benzimidazole/mercaptobenzimidale with chloro-N- substituted acetamide in the presence of potassium carbonate as a base catalyst in a microwave synthesiser.(Figure 1). Table 1 summarizes the physical properties of benzimidazole derivatives. All of the synthesised compounds were obtained in high purity and yield.

Table 1: Physical properties of synthesised N-substituted-2-substituted benzimidazole derivatives

\begin{tabular}{|c|l|l|l|l|l|}
\hline Compound & $\mathbf{R}_{\mathbf{1}}$ & $\mathbf{R}_{\mathbf{2}}$ & $\mathbf{m p ~}\left({ }^{\circ} \mathrm{C}\right)$ & Yield $(\%)$ & Rf value \\
\hline $5 \mathrm{a}$ & $\mathrm{H}$ & $\mathrm{H}$ & $224-228$ & 65.35 & 0.59 \\
\hline $5 \mathrm{~b}$ & $\mathrm{CH}_{3}$ & $\mathrm{H}$ & $218-220$ & 59.62 & 0.68 \\
\hline $5 \mathrm{c}$ & $4-\mathrm{Cl}$ & $\mathrm{H}$ & $198-202$ & 63.25 & 0.56 \\
\hline $5 \mathrm{~d}$ & $4-\mathrm{NO}_{2}$ & $\mathrm{H}$ & $266-268$ & 72.50 & 0.52 \\
\hline $5 \mathrm{e}$ & $2-\mathrm{NO}_{2}$ & $\mathrm{H}$ & $242-246$ & 70.65 & 0.51 \\
\hline $5 \mathrm{f}$ & $4-\mathrm{F}$ & $\mathrm{H}$ & $248-252$ & 62.35 & 0.57 \\
\hline $5 \mathrm{~g}$ & $4-\mathrm{OCH}_{3}$ & $\mathrm{H}$ & $184-186$ & 71.46 & 0.72 \\
\hline $5 \mathrm{~h}$ & $\mathrm{H}$ & $\mathrm{SH}$ & $242-246$ & 65.42 & 0.58 \\
\hline $5 \mathrm{i}$ & $\mathrm{CH}_{3}$ & $\mathrm{SH}$ & $248-252$ & 61.30 & 0.60 \\
\hline $5 \mathrm{j}$ & $4-\mathrm{Cl}$ & $\mathrm{SH}$ & $262-264$ & 64.20 & 0.59 \\
\hline $5 \mathrm{k}$ & $4-\mathrm{NO}_{2}$ & $\mathrm{SH}$ & $196-198$ & 75.25 & 0.62 \\
\hline $5 \mathrm{l}$ & $4-\mathrm{F}$ & $\mathrm{SH}$ & $232-238$ & 56.40 & 0.56 \\
\hline
\end{tabular}

The structure of solid substances was validated using elemental analysis. The derivatives were characterised using MS, ${ }^{1} \mathrm{H}$ NMR, ${ }^{13} \mathrm{C}$ NMR, and FTIR spectroscopy.N-H stretching band for secondary amide was obtained at $3337-3211 \mathrm{~cm}^{-}$ ${ }^{1}$ while stretching of the $\mathrm{C}=\mathrm{O}$ group of amides was observed at 1688 to $1652 \mathrm{~cm}^{-1}$ in the FTIR spectrum.A distinct peak for the aromatic proton of the benzoimidazole ring was found higher $\delta$ value than the phenyl ring was noted with the secondary amide peak at $\delta, 8.14-7.35$ in ${ }^{1} \mathrm{H}$ spectra. In the ${ }^{13} \mathrm{C}$ spectra amide carbon peak obtained at $\delta, 164-166$ and benzimidazole carbon at $\delta, 125-136$. These spectral results confirm the structure of the synthesised molecule.

\subsection{Docking study:}

Two targets were chosen for study: Staphylococcus aureus tyrosyl-tRNA synthetase (PDB: 1jij) and DNA gyrase subunit B (PDB: 513j).

The enzyme DNA gyrase is essential for DNA synthesis. DNA gyrase creates negative supercoils in the DNA next to the replication fork.[27,28]Tyrosyl-tRNA synthetase, on the other hand, mediates the covalent attachment of amino acids to their corresponding tRNA, resulting in charged tRNA, which is essential for protein synthesis. [3]As a result, these are a promising target enzyme for antibacterial drug development. [29,30]

The binding affinities of newly synthesized molecules and target proteins $1 \mathrm{jij}$ and $513 \mathrm{j}$ ) were investigated using molecular docking. All of the synthesized derivatives and amino acid in the binding pocket displayed significant bonding interactions, according to the docking results. Table 2 shows the amino acid interaction binding affinity of the Nsubstituted-2-substituted benzimidazole derivative to the target protein.

$\mathrm{N}$-substituted-2-substituted benzimidazole had a binding affinity of -7.3 to $-8.8 \mathrm{kcal} / \mathrm{mol}$ against Staphylococcus aureus tyrosyl-tRNA synthetase, whereas a binding affinity of -7.1 to $-8.8 \mathrm{kcal} / \mathrm{mol}$ against DNA gyrase subunit B, compared to reference ligand with binding affinity of $-7.9 \mathrm{kcal} / \mathrm{mol}$ and $-7.8 \mathrm{kcal} / \mathrm{mol}$ respectively. The benzimidazole derivatives interacts with amino acid in binding pocket through carbon hydrogen bonding, Pi-cation, Pi-anion, alkyl Pi-alkyl, van der waals, and traditional hydrogen bonding. Because of the amide in the structure, all of the derivatives exhibit a high affinity for t-RNA synthetase. 
International Advanced Research Journal in Science, Engineering and Technology

Vol. 8, Issue 6, June 2021

DOI: $10.17148 /$ IARJSET.2021.8691

5e has the lowest docking score of $-8.8 \mathrm{kcal} / \mathrm{mol}$ against to t-RNA synthetase and DNA gyrase subunit B. The bond length analysis shows that the 5e has a shorter bonding length than the typical ligand, implying that it binds better. The electron-withdrawing Nitro-group could be the cause of the strong binding. The docking energy of $5 \mathrm{~d}, 5 \mathrm{c}$, and $5 \mathrm{k}$ is the second lowest. Derivatives having electron withdrawing groups, such as chloro, fluro, and nitro, have a lower docking score, indicating substantial enzyme inhibition.

Fig. 2-9 show the 2D interaction of derivatives with the type of interaction and the $3 \mathrm{D}$ interaction of derivatives with the amino acid in the protein's binding pocket with the lowest docking score.

A.
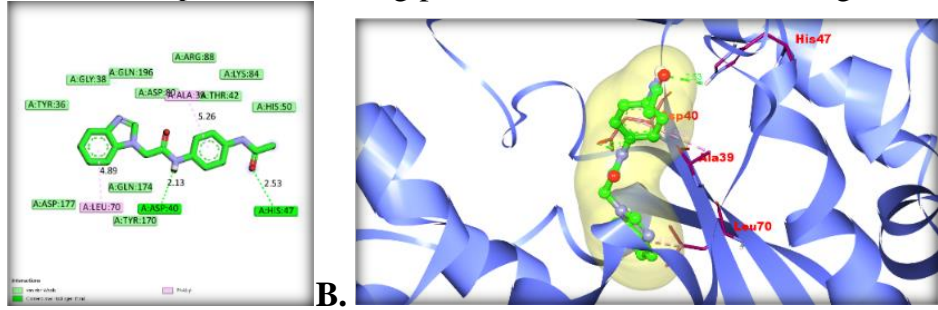

Fig.2. A- 2D interaction of 5e with tyrosyl t- RNA synthetase (1JIJ),

B-3D interaction of 5e with tyrosyl t- RNA synthetase (1JIJ)

A.
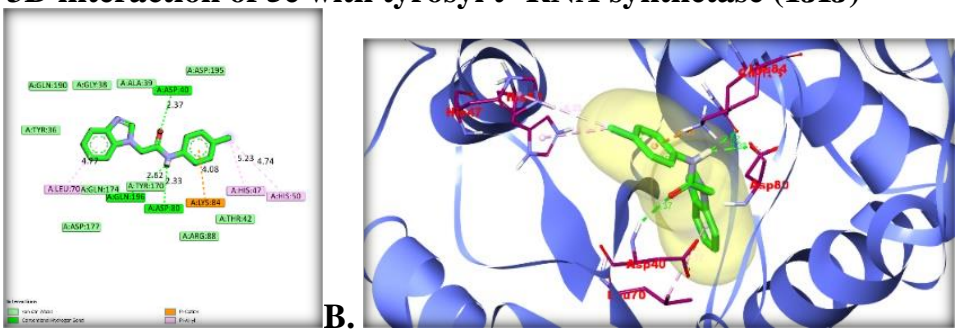

Fig.3. A- 2D interaction of 5c with tyrosyl t- RNA synthetase (1JIJ), B-3D interaction of $5 c$ with tyrosyl t- RNA synthetase (1JIJ)
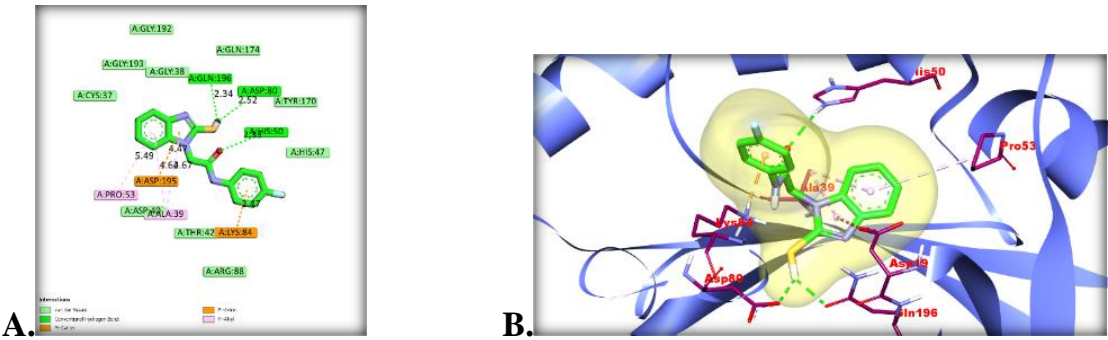

Fig.4. A: 2D interaction of 5k with tyrosyl t- RNA synthetase (1JIJ) B: 3D interaction of 5k with tyrosyl t- RNA synthetase (1JIJ)
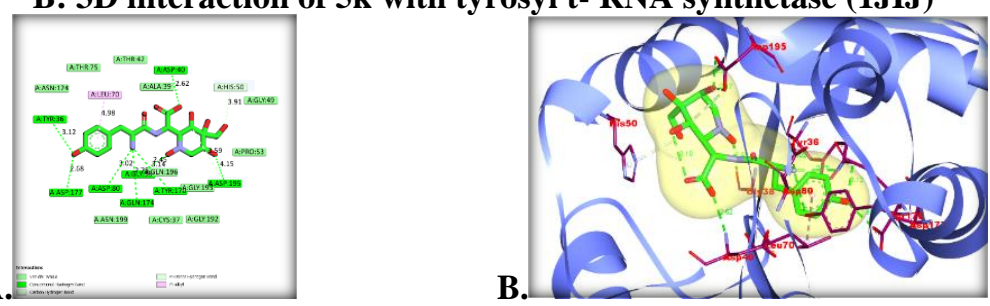

Fig.5. A: 2D interaction of Ligand with tyrosyl t- RNA synthetase (1JIJ)

B: 3D interaction of Ligand with tyrosyl t- RNA synthetase (1JIJ)
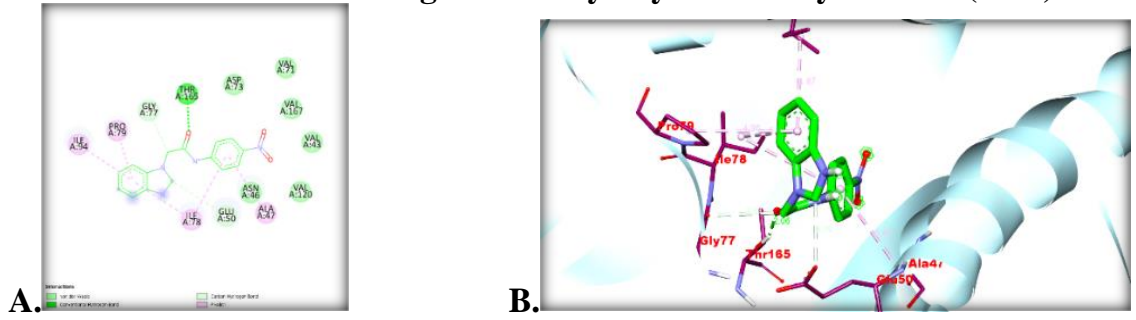

Fig.6. A: 2D interaction of 5d with DNA gyrase subunit B (513j) B: 3D interaction of 5d with DNA gyrase subunit B (513j) 
International Advanced Research Journal in Science, Engineering and Technology

Vol. 8, Issue 6, June 2021

DOI: $10.17148 / I A R J S E T .2021 .8691$
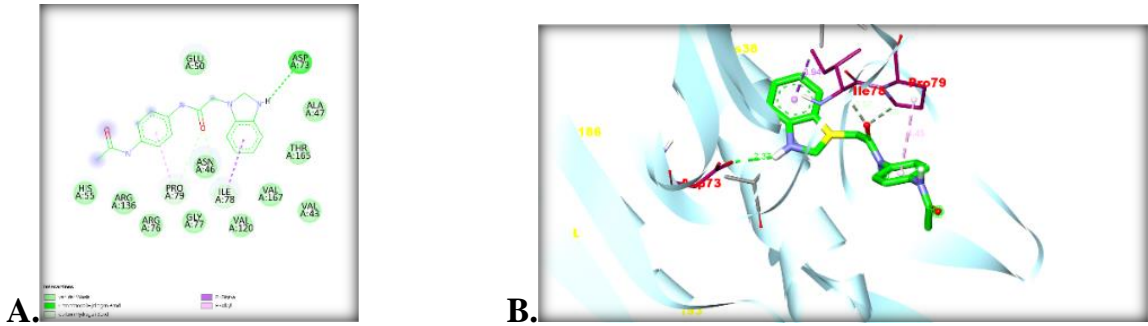

Fig.7. A: 2D interaction of 5e with DNA gyrase subunit B (5l3j)

B: 3D interaction of 5e with DNA gyrase subunit B (513j)
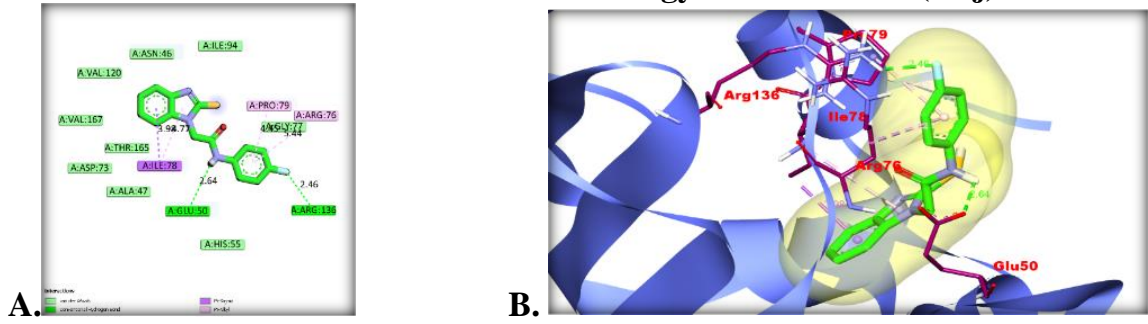

Fig.8. A: 2D interaction of MB5 with DNA gyrase subunit B (513j)

B: 3D interaction of MB5 with DNA gyrase subunit B (513j)
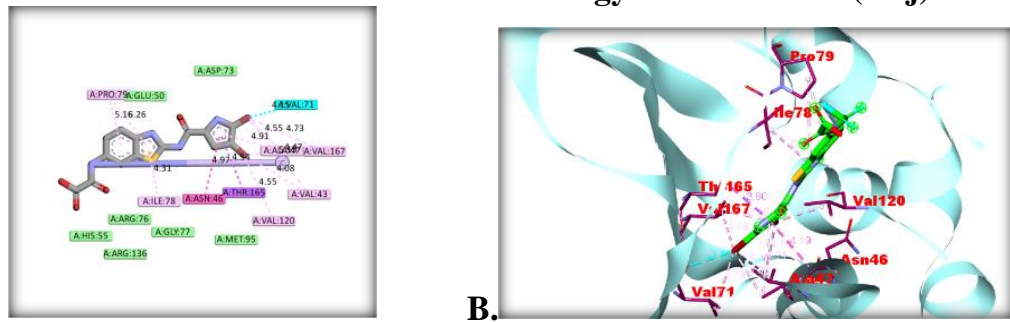

Fig.9. A: 2D interaction of Ligand with DNA gyrase subunit B (513j) B: 3D interaction of Ligand with DNA gyrase subunit B (513j)

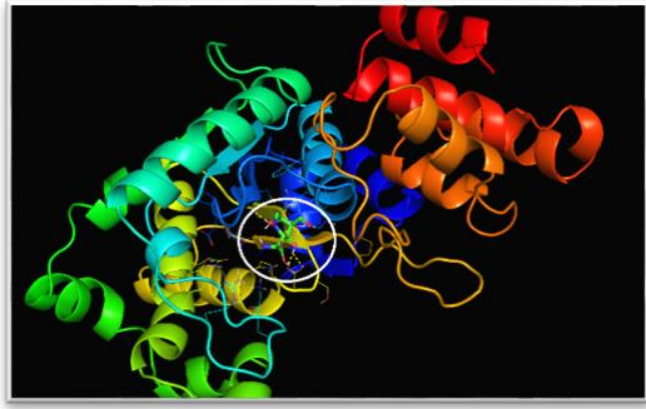

A.

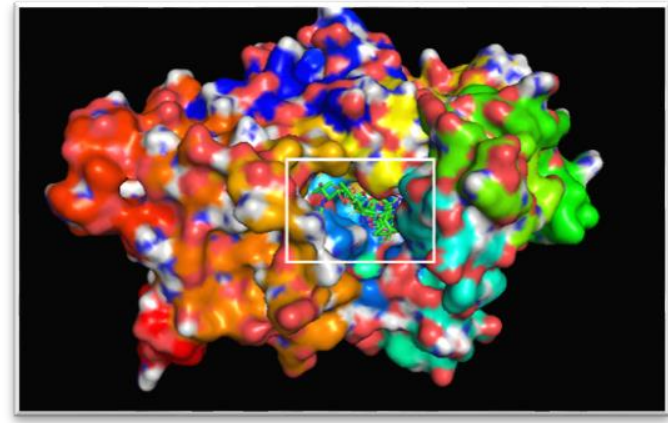

B.
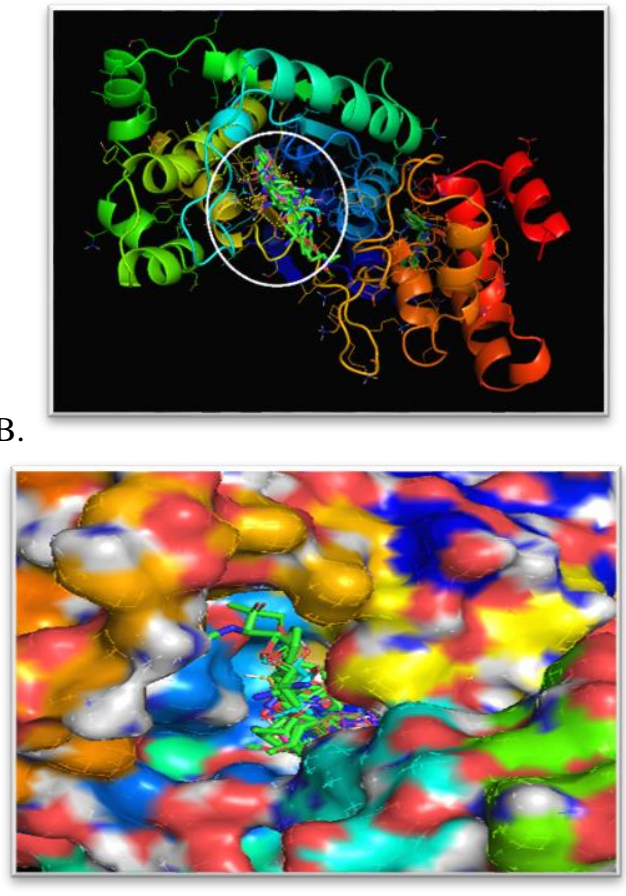

Fig.10. A: Interaction of Ligand in active site of Receptor

B: Interaction of All derivative in active site of Receptor

C: Surface display of receptor active site

D. Interaction of derivatives in surface display 
International Advanced Research Journal in Science, Engineering and Technology

Vol. 8, Issue 6, June 2021

DOI: 10.17148/IARJSET.2021.8691

Table 1: Binding score and interaction of benzimidazole derivatives with proteins

\begin{tabular}{|c|c|c|c|c|c|c|}
\hline \multirow{2}{*}{$\begin{array}{l}\text { Co } \\
\text { mp } \\
\text { Co } \\
\text { de }\end{array}$} & \multicolumn{3}{|c|}{ Protein 1jij } & \multicolumn{3}{|c|}{ Protein 5l3j } \\
\hline & $\begin{array}{l}\text { Bindin } \\
\text { g } \\
\text { affinit } \\
\text { y } \\
\text { (kcal/ } \\
\text { mol) }\end{array}$ & $\begin{array}{l}\text { Type of } \\
\text { interaction }\end{array}$ & Interacting Amino acid & $\begin{array}{l}\text { Bindin } \\
\text { g } \\
\text { affinit } \\
\text { y } \\
\text { (kcal/ } \\
\text { mol) }\end{array}$ & $\begin{array}{ll}\text { Type } & \text { of } \\
\text { interaction }\end{array}$ & $\begin{array}{l}\text { Interacting } \\
\text { Amino acid }\end{array}$ \\
\hline $5 a$ & -8.2 & $\begin{array}{l}\text { Conventional } \\
\text { Hydrogen bond, Pi- } \\
\text { Cation, Pi- } \\
\text { Alkyl,Van der } \\
\text { Waals, }\end{array}$ & $\begin{array}{lll}\text { Tyr36, } & \text { Gly38, } & \text { Ala39, } \\
\text { Asp40, } & \text { Thr42, } & \text { His50, } \\
\text { Leu70, } & \text { Asp80, } & \text { Ser82, } \\
\text { Lys84, } & \text { Arg88, } & \text { Tyr170, } \\
\text { Gln174, } & \text { Asp177, } & \text { Gln190, } \\
\text { Asp195, } & \text { Gln196 } & \\
\end{array}$ & -7.2 & $\begin{array}{l}\text { Conventional } \\
\text { hydrogen bond, } \\
\text { Pi-alkyl, Van } \\
\text { der waals }\end{array}$ & $\begin{array}{lr}\text { Val43, } & \text { Asp73, } \\
\text { Glu50, } & \text { Asp49, } \\
\text { Asn46, } & \text { Ala47, } \\
\text { Ile78, Pro79, Ile94, } \\
\text { Val120, Thr165, } \\
\text { Val167, }\end{array}$ \\
\hline $5 b$ & -8.3 & $\begin{array}{l}\text { Conventional } \\
\text { Hydrogen bond, } \\
\text { Carbon hydrogen } \\
\text { Bond, Pi-Cation, } \\
\text { Pi-Alkyl,Van der } \\
\text { Waals, }\end{array}$ & $\begin{array}{lcc}\text { Tyr36, } & \text { Gly38, } & \text { Ala39, } \\
\text { Asp40, } & \text { Thr42, } & \text { His50, } \\
\text { Leu70, } & \text { Asp80, } & \text { Thr75, } \\
\text { Lys84, } & \text { Arg88, } & \text { Tyr170, } \\
\text { Gln174, } & \text { Asp177, } & \text { Gln190, } \\
\text { Asp195, } & \text { Gln196 } & \\
\end{array}$ & -7.3 & $\begin{array}{l}\text { Conventional } \\
\text { hydrogen bond, } \\
\text { Pi- anion, Pi- } \\
\text { alkyl, Van der } \\
\text { waals }\end{array}$ & $\begin{array}{lr}\text { Val43, } & \text { Asn46, } \\
\text { Ala47, } & \text { Asp49, } \\
\text { Asp73, } & \text { Val120, } \\
\text { Val167, } & \text { Glu50, } \\
\text { Ile78, } & \text { Ile94, } \\
\text { Thr165 } & \\
\end{array}$ \\
\hline $5 c$ & -8.4 & $\begin{array}{l}\text { Conventional } \\
\text { Hydrogen bond, Pi- } \\
\text { Cation, Pi- } \\
\text { Alkyl,Van der } \\
\text { Waals, }\end{array}$ & $\begin{array}{llr}\text { Tyr36, } & \text { Gly38, } & \text { Ala39, } \\
\text { Asp40, } & \text { Thr42, } & \text { His47, } \\
\text { His50, } & \text { Leu70, } & \text { Asp80, } \\
\text { Lys84, } & \text { Arg88, } & \text { Tyr170, } \\
\text { Gln174, } & \text { Asp177, } & \text { Gln190, } \\
\text { Asp195, Gln196 } & \end{array}$ & -7.3 & $\begin{array}{l}\text { Conventional } \\
\text { hydrogen bond, } \\
\text { Pi- sigma, } \\
\text { Alkyl, Pi-alkyl, } \\
\text { Van der waals }\end{array}$ & $\begin{array}{lr}\text { Val43, } & \text { Asn46, } \\
\text { Ala47, } & \text { Asp73, } \\
\text { Arg76, } & \text { Gly77, } \\
\text { Ile94, } & \text { Arg136, } \\
\text { Thr165, } & \text { Val167, } \\
\text { Glu50, } & \text { Ile78, } \\
\text { Pro79, Val120 }\end{array}$ \\
\hline $5 d$ & -8.7 & $\begin{array}{l}\text { Conventional } \\
\text { Hydrogen bond, Pi- } \\
\text { Cation, Pi- } \\
\text { Alkyl,Van der } \\
\text { Waals, }\end{array}$ & 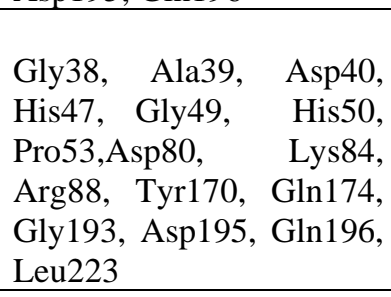 & -7 . & $\begin{array}{l}\text { Conventional } \\
\text { hydrogen bond, } \\
\text { Pi-alkyl, Van } \\
\text { der waals }\end{array}$ & $\begin{array}{lr}\text { Ala47, } & \text { Glu50, } \\
\text { Gly77, } & \text { Ile78, } \\
\text { Pro79, } & \text { Ile94, } \\
\text { Thr165, } & \text { Val43, } \\
\text { Asn46, } & \text { Val71, } \\
\text { Asp73, } & \text { Val120, } \\
\text { Val167 } & \\
\end{array}$ \\
\hline $5 e$ & -8.8 & $\begin{array}{l}\text { Conventional } \\
\text { Hydrogen bond, } \\
\text { Pi-Cation, Pi- } \\
\text { Alkyl, Van der } \\
\text { Waals, }\end{array}$ & $\begin{array}{lll}\text { Tyr36, } & \text { Gly38, } & \text { Ala39, } \\
\text { Asp40, } & \text { Thr42, } & \text { His50, } \\
\text { Leu70, } & \text { Thr75, } & \text { Asp80, } \\
\text { Ser82, } & \text { Lys84, } & \text { Arg88, } \\
\text { Asn124, } & \text { Tyr170, } & \text { Gln174, } \\
\text { Asp177, } & \text { Gln190, } & \text { Asp195, } \\
\text { Gln196 } & \end{array}$ & -8 & $\begin{array}{l}\text { Conventional } \\
\text { hydrogen bond, } \\
\text { Carbon } \\
\text { Hydrogen } \\
\text { Bond, Pi- } \\
\text { sigma, Pi-alkyl, } \\
\text { Van der waals } \\
\end{array}$ & $\begin{array}{lr}\text { Val43, } & \text { Ala47, } \\
\text { Asn46, } & \text { Glu50, } \\
\text { His55, } & \text { Arg76, } \\
\text { Gly77, } & \text { Arg136, } \\
\text { Val120, } & \text { Thr165, } \\
\text { Val167, } & \text { Asp73, } \\
\text { Ile78, Pro79 } \\
\end{array}$ \\
\hline $5 f$ & -8.4 & $\begin{array}{l}\text { Conventional } \\
\text { Hydrogen bond, } \\
\text { Halogren(Fluorine) } \\
\text {,Pi- Anion, Pi- } \\
\text { Donor Hydrogen } \\
\text { Bond, Pi-Alkyl, } \\
\text { Van der Waals, }\end{array}$ & $\begin{array}{l}\text { Tyr36, Gly38, Ala39, } \\
\text { Asp40, His50, Leu70, } \\
\text { Asp80, Thr75, Asn124, } \\
\text { Tyr170, Gln174, Asp177, } \\
\text { Gly193, Asp195, Gln196, } \\
\text { Asn199 }\end{array}$ & -7.1 & $\begin{array}{l}\text { Conventional } \\
\text { hydrogen bond, } \\
\text { Pi-anion, Pi- } \\
\text { sigma, Pi-alkyl, } \\
\text { Van der waals }\end{array}$ & $\begin{array}{lr}\text { Val43, } & \text { Ala47, } \\
\text { Asn46, } & \text { Glu50, } \\
\text { Ala53, } & \text { His55, } \\
\text { Arg76, } & \text { Gly77, } \\
\text { Pro79, } & \text { Ile94, } \\
\text { Arg136, } & \text { Val120, } \\
\text { Thr165, Val167. } \\
\end{array}$ \\
\hline 20 & -8.1 & $\begin{array}{l}\text { Conventional } \\
\text { Hydrogen bond, } \\
\text { Carbon hydrogen } \\
\text { Bond, Pi-Cation, } \\
\text { Pi-Alkyl, Van der } \\
\text { Waals, }\end{array}$ & $\begin{array}{lcc}\text { Tyr36, } & \text { Gly38, } & \text { Ala39, } \\
\text { Asp40, } & \text { Thr42, } & \text { His50, } \\
\text { Leu70, } & \text { Thr75, } & \text { Asp80, } \\
\text { Lys84, Arg88, Asn124, } & \text { Asn } \\
\text { Tyr170, Gln174, Asp177, } & \text { Aln190, Asp195, Gln196 } \\
\text { Gln190 }\end{array}$ & -7.1 & $\begin{array}{l}\text { Conventional } \\
\text { hydrogen bond, } \\
\text { Carbon- } \\
\text { hydrogen bond, } \\
\text { Pi-sigma, } \\
\text { Alkyl, Pi-alkyl, } \\
\text { Van der waals } \\
\end{array}$ & $\begin{array}{lr}\text { Ala47, } & \text { Asn46, } \\
\text { Glu50, } & \text { His55, } \\
\text { Arg76, } & \text { Asp73, } \\
\text { Gly77, } & \text { Ile78, } \\
\text { Pro79, } & \text { Ile94, } \\
\text { Val120, } & \text { Arg 136, } \\
\text { Thr165, Val167 } \\
\end{array}$ \\
\hline
\end{tabular}


DOI: 10.17148/IARJSET.2021.8691

\begin{tabular}{|c|c|c|c|c|c|c|}
\hline $5 \mathrm{~h}$ & -7.3 & $\begin{array}{l}\text { Van der Waals, } \\
\text { Carbon hydrogen } \\
\text { Bond, Pi-Donar } \\
\text { hydrogen bond, Pi- } \\
\text { Alkyl }\end{array}$ & 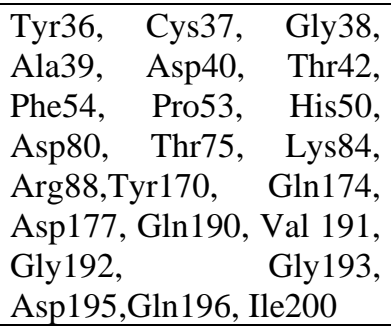 & -6.6 & $\begin{array}{l}\text { van der waals, } \\
\text { Amide-pi- } \\
\text { stackedPi- } \\
\text { sigma Pi-alkyl, }\end{array}$ & $\begin{array}{l}\text { Val43, } \\
\text { Ala47,Asn46, } \\
\text { Glu50, Ala53, } \\
\text { Asp73, Gly77, } \\
\text { Ile78, Pro79, Ile 94, } \\
\text { Arg136, Val120, } \\
\text { Thr165, Val167 }\end{array}$ \\
\hline $5 \mathrm{i}$ & -7.4 & $\begin{array}{l}\text { Van der Waals, Pi- } \\
\text { Cation, Pi-anion, } \\
\text { Pi- sigma, Pi-Pi -T- } \\
\text { Shaped, Amide- Pi- } \\
\text { Stacked, Alkyl }\end{array}$ & $\begin{array}{l}\text { Val 4, Glu7, Trp11, Asp8, } \\
\text { Arg12, His6., } \\
\text { Agre273, } \\
\text { Gly275, Lys276. }\end{array}$ & -8.1 & $\begin{array}{l}\text { van der waals, } \\
\text { Carbon } \\
\text { Hydrogen } \\
\text { Bond, Alkyl, } \\
\text { Pi-alkyl, }\end{array}$ & $\begin{array}{l}\text { Val43, } \\
\text { Ala47,Asn46, } \\
\text { Asp49, Glu50, } \\
\text { Ala53, Asp73, } \\
\text { Ile78, Pro79, Ile 94, } \\
\text { Met95, Val120, } \\
\text { Thr165, Val167 }\end{array}$ \\
\hline $5 \mathrm{j}$ & -7.4 & $\begin{array}{l}\text { Van der Waals, Pi- } \\
\text { Cation, Pi-anion, } \\
\text { Pi- sigma, Pi-Pi -T- } \\
\text { Shaped, Amide- Pi- } \\
\text { Stacked, Alkyl }\end{array}$ & 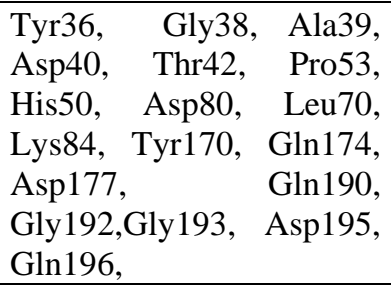 & -7.5 & $\begin{array}{l}\text { van der waals, } \\
\text { Conventional } \\
\text { Hydrogen } \\
\text { Bond, Pi- } \\
\text { sigma, Alkyl, } \\
\text { Pi-alkyl, }\end{array}$ & $\begin{array}{l}\text { Ala47,Asn46, } \\
\text { Glu50, His55, } \\
\text { Asp73,Arg76, } \\
\text { Gly77, Ile78, } \\
\text { Pro79, Ile 94, } \\
\text { Arg136, Val120, } \\
\text { Thr165, Val167 }\end{array}$ \\
\hline $5 \mathrm{k}$ & -8.3 & $\begin{array}{l}\text { Van der Waals, } \\
\text { Conventional } \\
\text { Hydrogen Bond, } \\
\text { Carbon Hydrogen } \\
\text { Bond, Pi-anion, Pi- } \\
\text { Pi -T- Shaped, } \\
\text { Alkyl, Pi- Alkyl }\end{array}$ & 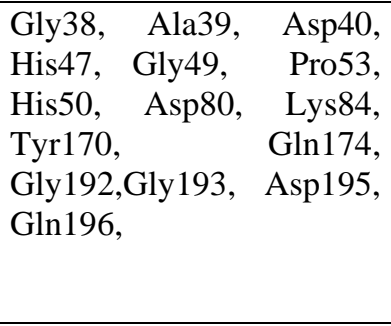 & -7.1 & $\begin{array}{l}\text { van der waals, } \\
\text { Conventional } \\
\text { Hydrogen } \\
\text { Bond, Pi- } \\
\text { sigma, Amide- } \\
\text { pi-stacked, Pi- } \\
\text { alkyl, }\end{array}$ & $\begin{array}{l}\text { Val43, } \\
\text { Ala47,Asn46,Asp4 } \\
\text { 9, Glu50, Ala53, } \\
\text { Asp73,Gly75, } \\
\text { Arg76, Gly77, } \\
\text { Ile78, Ile 94, } \\
\text { Val120, Thr165, } \\
\text { Val167 }\end{array}$ \\
\hline 51 & -8.1 & $\begin{array}{l}\text { Van der Waals, } \\
\text { Conventional } \\
\text { Hydrogen Bond,Pi- } \\
\text { cation,Pi-anion, } \\
\text { Pi- Alkyl }\end{array}$ & $\begin{array}{lcc}\text { Cys37, } & \text { Gly38, } & \text { Ala39, } \\
\text { Asp40, } & \text { Thr42, } & \text { His47, } \\
\text { Gly49, } & \text { Pro53, } & \text { His50, } \\
\text { Asp80, Lys84, } & \text { Arg88, } \\
\text { Tyr170, } & \text { Gln174, } \\
\text { Gly192,Gly193, } & \text { Asp195, } \\
\text { Gln196, } & \end{array}$ & -7.8 & $\begin{array}{l}\text { van der waals, } \\
\text { Conventional } \\
\text { Hydrogen } \\
\text { Bond, Pi- } \\
\text { sigma, Pi-alkyl, }\end{array}$ & $\begin{array}{l}\text { Ala47,Asn46,Glu5 } \\
0, \quad \text { His55, } \\
\text { Asp73,Gly75, } \\
\text { Arg76, Gly77, } \\
\text { Ile78, Ile 94, } \\
\text { Val120, Arg136, } \\
\text { Thr165, Val167 }\end{array}$ \\
\hline $\begin{array}{l}\text { Lig } \\
\text { an } \\
\text { d }\end{array}$ & -7.9 & $\begin{array}{l}\text { Van der Waals, } \\
\text { Conventional } \\
\text { Hydrogen Bond, } \\
\text { Carbon Hydrogen } \\
\text { Bond, Pi-Donar } \\
\text { Hydrogen Bond, } \\
\text { Pi- Alkyl }\end{array}$ & 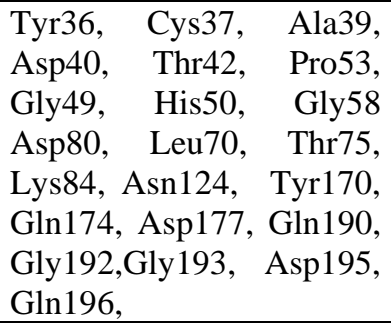 & -7.8 & $\begin{array}{l}\text { Conventional } \\
\text { hydroge Bond, } \\
\text { Pi- sigma Pi- } \\
\text { alkyl, van der } \\
\text { waals }\end{array}$ & $\begin{array}{lr}\text { Ala47, } & \text { Asn46, } \\
\text { Asp49, } & \text { Glu50, } \\
\text { His55, } & \text { Asp73, } \\
\text { Gly77, } & \text { Arg76, } \\
\text { Ile78, } & \text { Ile 94, } \\
\text { Val120, } & \text { Arg136, } \\
\text { Thr165, Val167 }\end{array}$ \\
\hline
\end{tabular}

\section{CONCLUSION}

Microwave aided synthesis was used to produce new N-substituted-2-substituted benzimidazole derivatives. Compounds $5 \mathrm{c}, 5 \mathrm{~d}, 5 \mathrm{e}$, and 5k exhibit considerable enzyme inhibitory activity, implying that they may have significant antibacterial potential. Further insights of SAR study can alter the activity of derivatives and can lead to the development of alternative antibacterial agent.

\section{ACKNOWLEDGEMENTS}

The author is especially grateful to the Management, Principal, and Faculty of PES's Modern College of Pharmacy and GES's Sir Dr. M. S. Gosavi College of Pharmaceutical Education and Research for providing facility and support to carry out the study. The author is thankful to SAIF, IIT Bombay for providing instrumental analysis of compound. 


\section{International Advanced Research Journal in Science, Engineering and Technology}

Vol. 8, Issue 6, June 2021

DOI: $10.17148 /$ IARJSET.2021.8691

\section{REFERENCES}

1. Hay SI, Battle KE, Pigott DM, Smith DL, Moyes CL, Bhatt S, et al. "Global mapping of infectious disease". 36820120250. Philosophical Transactions of the Royal Society B: Biological Sciences, 2013.

2. Nandwana NK, Singh RP, Patel OPS, Dhiman S, Saini HK, Jha PN, et al. "Design and Synthesis of Imidazo/Benzimidazo[1,2c]quinazoline Derivatives and Evaluation of Their Antimicrobial Activity". 3(11),16338-46. ACS Omega, 2018.

3. Pisano MB, Kumar A, Medda R, Gatto G, Pal R, Fais A, et al. "Antibacterial Activity and Molecular Docking Studies of a Selected Series of Hydroxy-3-arylcoumarins". 24(15),1-12. Molecules, 2019.

4. Pandya, Keyur M. Desai, piyush S., Patel, Navin B., Dave BP. "Synthesis and Antimicrobial Study of Novel Heterocycles Azetidinone, Benzotriazole and 1,3,4-Oxadiazole Moieties". 8(5),314-22. Chemistry \& Biology Interface, 2018.

5. Wan J, Peng-Cheng L V., Tian NN, Zhu HL. "Facile synthesis of novel benzotriazole derivatives and their antibacterial activities". 122(4),597-606. Journal of Chemical Sciences, 2010.

6. Janeczko M, Kazimierczuk Z, Orzeszko A, Niewiadomy A, Król E, Szyszka R, et al. "In search of the antimicrobial potential of benzimidazole derivatives". 65(3),359-64. Polish Journal of Microbiology, 2016

7. Hsieh CY, Ko PW, Chang YJ, Kapoor M, Liang YC, Chu HL, et al. "Design and synthesis of benzimidazole-chalcone derivatives as potential anticancer agents". 24(18),. Molecules, 2019.

8. Rajasekaran S, Rao G, Chatterjee A. "Synthesis, anti-inflammatory and anti-oxidant activity of some substituted benzimidazole derivatives". 4(3),303-9. International Journal of Drug Development and Research, 2012

9. Abdel-Motaal M, Almohawes K, Tantawy MA. "Antimicrobial evaluation and docking study of some new substituted benzimidazole-2yl derivatives". 101103972. Bioorganic Chemistry, 2020.

10. Picconi P, Hind C, Jamshidi S, Nahar K, Clifford M, Wand ME, et al. "Triaryl Benzimidazoles as a New Class of Antibacterial Agents against Resistant Pathogenic Microorganisms". 60(14),6045-59. Journal of Medicinal Chemistry, 2017.

11. Harte AJ, Gunnlaugsson T. "Synthesis of $\alpha$-chloroamides in water". 47(35),6321-4. Tetrahedron Letters, 2006.

12. Mishra D, Singh R, Rout C. "A facile amidation of chloroacetyl chloride using DBU". 10(3),365-72. International Journal of ChemTech Research, 2017.

13. Patil AS, Ram BG, Mahajan SK, Amrutkar S V. "Synthesis of N- ( Alkyl or Aryl ) -2- ( 1 H -benzotriazol-1-yl ) -acetamides as selective COX-2 inhibitor". 5(1),1-4. Journal of Pharmaceutical Science \& Research, 2013.

14. Furniss, B.S.; Hannaford, A.J.; Smith, P.W.G.; Tatchell AR. "Vogel's Textbook of Practical Organic Chemistry". 1162-1163 p. 2004

15. Wang ML, Liu BL. "Synthesis of 2-mercaptobenzimidazole from the reaction of o-phenylene diamine and carbon disulfide in the presence of potassium hydroxide". 38(2),161-7. Journal of the Chinese Institute of Chemical Engineers, 2007.

16. Deacon JAV and BD. "2-Mercaptobenzimidazole". 30(September),56. Organic Syntheses, 1950

17. Heralagi R V, Jayaveera KN, Shivkumar B, June A. "Synthesis of Some Novel Bis Type 2-Mercapto Benzimidazole Derivatives".

3(2),407-14. Research Journal of Pharmaceutical , Biological and Chemical Sciences, 2012.

18. Saxena P, Singh DCP, Ali A, Sharma V. "Synthesis of some derivatives of 2-mercaptobenzothiazole and their evaluation as antiinflammatory agents". 5(1),454-8. International Journal of Pharmacy and Pharmaceutical Sciences, 2013.

19. DeLano WL. "Pymol: An open-source molecular graphics tool". 40(1),82-92. Newsletter On Protein Crystallography, 2002.

20. BIOVIA DS. "Discovery Studio Modeling Environment. San Diego: Dassault Systèmes". 2017.

21. Gadhave R, Vichare V, Joshi S. "Synthesis and Biological Evaluation for Antihistaminic activity of N1-Alkyl- 2(N4-Alkyl/Aryl piperazinyl methyl) Benzimidazole derivatives". 5(7),918-21. Asian Journal of Research In Chemistry, 2012.

22. O’Boyle NM, Banck M, James CA, Morley C, Vandermeersch T, Hutchison GR. "Open Babel". 3(33),1-14. Journal of Cheminformatics,

2011 .

23. Dallakyan S, Olson AJ. "Small-molecule library screening by docking with PyRx". 1263(January),243-50. Methods in Molecular Biology,

2015.

24. Ghannam IAY, Abd El-Meguid EA, Ali IH, Sheir DH, El Kerdawy AM. "Novel 2-arylbenzothiazole DNA gyrase inhibitors: Synthesis, antimicrobial evaluation, QSAR and molecular docking studies". 93103373. Bioorganic Chemistry, 2019.

25. Trott O, Olson AJ. "AutoDock Vina: Improving the speed and accuracy of docking with a new scoring function, efficient optimization, and multithreading". 31(2),NA-NA. Journal of Computational Chemistry, 2009.

26. Ismail RA, Baba HH, Muhammad SA, Abdulkadir A, Mustapha BM, Shitu MI. "Virtual Screening, Molecular Docking, and Adme / T Properties Analysis of Repellent Efficacy of Natural Compounds on Dermestes Maculatus of Protopterus Annectens". 5(6),255-63. 2020.

27. Durojaye OA, Ugochi N, Samuel C, Akpan EN. "In-Silico Structure-Activity Relationship and Molecular Docking Study of Levofloxacin and its Monosubstitted Analogues against the Escherichia coli DNA Gyrase A R T I C L E I N F O ... International Journal of Chemistry and In-Silico Structure-Activity Re". (September),1-7. 2018.

28. Islam MA, Pillay TS. "Identification of promising anti-DNA gyrase antibacterial compounds using de novo design, molecular docking and molecular dynamics studies". 38(6),1798-809. Journal of Biomolecular Structure and Dynamics, 2020.

29. Gullapelli K, Brahmeshwari G, Ravichander M, Kusuma U. "Synthesis, antibacterial and molecular docking studies of new benzimidazole derivatives". 4(4),303-9. Egyptian Journal of Basic and Applied Sciences, 2017.

30. Athar F, Ansari S, Beg MA. "Molecular docking studies of Calotropis gigantea phytoconstituents against Staphylococcus aureus tyrosyltRNA synthetase protein". 8(3),78-91. Journal of Bacteriology \& Mycology: Open Access, 2020.

31. Neha G. Relan and Prof. Dharmaraj R. Patil. "Implementation of Network Intrusion Detection System using Variant of Decision Tree Algorithm." In International Conference on Nascent Technologies in the Engineering Field (ICNTE), pp. 4799-7263. IEEE, 2015.

32. Wentao Liu. "Research on DOS Attack and Detection Programming." In Third International Symposium on Intelligent Information Technology Application (ISIITA), pp. 7695-3859. IEEE, 2009.

33. Ivan Burmaka, Stanislav Zlobin, Svitlana Lytvyn and Valentin Nekhai. "Detecting Flood Attacks and Abnormal System Usage with Artificial Immune System." International Scientific-Practical Conference on Mathematical Modeling and Simulation of Systems (MODS), pp. 131143. Springer, 2019.

34. Poonam Jagannath Shinde and Madhumita Chatterjee. "A Novel Approach for Classification and Detection of DOS Attacks." In International Conference on Smart City and Emerging Technology (ICSCET), pp. 1109-8537. IEEE, 2018.

35. Neha G. Relan and Prof. Dharmaraj R. Patil. "Implementation of Network Intrusion Detection System using Variant of Decision Tree Algorithm." In International Conference on Nascent Technologies in the Engineering Field (ICNTE), pp. 4799-7263. IEEE, 2015.

36. Wentao Liu. "Research on DOS Attack and Detection Programming." In Third International Symposium on Intelligent Information Technology Application (ISIITA), pp. 7695-3859. IEEE, 2009. 


\section{International Advanced Research Journal in Science, Engineering and Technology}

Vol. 8, Issue 6, June 2021

\section{DOI: $10.17148 / I A R J S E T .2021 .8691$}

37. Ivan Burmaka, Stanislav Zlobin, Svitlana Lytvyn and Valentin Nekhai. "Detecting Flood Attacks and Abnormal System Usage with Artificial Immune System." International Scientific-Practical Conference on Mathematical Modeling and Simulation of Systems (MODS), pp. 131143. Springer, 2019.

38. 1. Benamar Bouyeddou, Fouzi Harrou, Ying Sun and Benamar Kadri. "Detecting SYN Flood Attacks via Statistical Monitoring Charts: A Comparative Study." In The 5th International Conference on Electrical Engineering (ICEE-B), pp. 5386-6869. IEEE, Boumerdes, Algeria, 2017.

39. $\quad$ Poonam Jagannath Shinde and Madhumita Chatterjee. "A Novel Approach for Classification and Detection of DOS Attacks." In International Conference on Smart City and Emerging Technology (ICSCET), pp. 1109-8537. IEEE, 2018.

40. Neha G. Relan and Prof. Dharmaraj R. Patil. "Implementation of Network Intrusion Detection System using Variant of Decision Tree Algorithm." In International Conference on Nascent Technologies in the Engineering Field (ICNTE), pp. 4799-7263. IEEE, 2015.

41. Wentao Liu. "Research on DOS Attack and Detection Programming." In Third International Symposium on Intelligent Information Technology Application (ISIITA), pp. 7695-3859. IEEE, 2009.

42. Ivan Burmaka, Stanislav Zlobin, Svitlana Lytvyn and Valentin Nekhai. "Detecting Flood Attacks and Abnormal System Usage with Artificial Immune System." International Scientific-Practical Conference on Mathematical Modeling and Simulation of Systems (MODS), pp. 131143. Springer, 2019.

43. Poonam Jagannath Shinde and Madhumita Chatterjee. "A Novel Approach for Classification and Detection of DOS Attacks." In International Conference on Smart City and Emerging Technology (ICSCET), pp. 1109-8537. IEEE, 2018.

44. Neha G. Relan and Prof. Dharmaraj R. Patil. "Implementation of Network Intrusion Detection System using Variant of Decision Tree Algorithm." In International Conference on Nascent Technologies in the Engineering Field (ICNTE), pp. 4799-7263. IEEE, 2015.

45. Poonam Jagannath Shinde and Madhumita Chatterjee. "A Novel Approach for Classification and Detection of DOS Attacks." In International Conference on Smart City and Emerging Technology (ICSCET), pp. 1109-8537. IEEE, 2018.

46. Neha G. Relan and Prof. Dharmaraj R. Patil. "Implementation of Network Intrusion Detection System using Variant of Decision Tree Algorithm." In International Conference on Nascent Technologies in the Engineering Field (ICNTE), pp. 4799-7263. IEEE, 2015. 